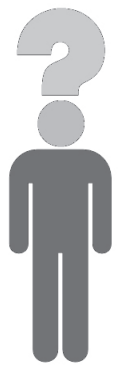

Łukasz Krężołek

\title{
WOLNOŚĆ I PROBLEM CNOTY WE WSPÓŁCZESNEJ MYŚLI REPUBLIKAŃSKIEJ
}

Debata nad kondycją współczesnej demokracji liberalnej wydaje się przybierać na sile. Podnoszone są argumenty o niewydolności modelu wynikającej ze sprzecznych wewnętrznych tendencji. Liberalna demokracja bowiem, postrzegając się jako narzędzie upodmiotowania ludzi, jednocześnie - zgodnie z paradygmatem liberalnym - pozwala im funkcjonować poza właściwym polem politycznym. Możliwość wyjścia poza wspólnotę polityczną, choć powodowana nieskrępowaną wolą podmiotu, jednocześnie niesie za sobą ryzyko alienacji. Świadomość tych tendencji można uznać za źródło pojawienia się licznych modeli teoretycznych, które za cel obrały sobie korektę demokracji liberalnej. Wśród tych można wymienić choćby libertarianizm, komunitaryzm, demokrację radykalną czy wreszcie nowoczesny republikanizm.

Przekonanie o znaczeniu republikanizmu dla rozwoju „,atlantyckiej tradycji myśli politycznej" znalazło licznych zwolenników, wśród których na szczególną uwagę zasługuje Quentin Skinner ${ }^{1}$. To on wyeksponował kwestię specyficznego dla tradycji republikańskiej, innego od stanowiska liberalnego, sposobu ujmowania wolności, który wymyka się popularnej dychotomii zaproponowanej przez Isaiaha Berlina. Opierając się na tradycji klasycznej (powiązanej z renesansem florenckim), Skinner połączył wolność poszczególnych jednostek z wolnością wspólnoty politycznej i wykazał ich komplementarność. Myśl Skinnera rozwijał Philip Pettit, autor szczególnie ważnej publikacji Republicanism. A theory of freedom and government (Oxford 1997). Myśl Pettita można wiązać z próbą unowocześnienia klasycznej myśli republikańskiej nazywa-

1 Q. Skinner, Powrót wielkiej teorii w naukach humanistycznych, red. B. Szlachta, przekł. P. Łozowski, Lublin 1998. 
nej czasem neorepublikanizmem (neo-republicanism lub civic republicanism), postrzeganej jako szansa dokonania wspomnianej korekty obowiązującego paradygmatu liberalnego².

Wyjaśnienie przedstawionego tu rozróżnienia i wynikłych z niego konsekwencji (w szczególności znaczenia prawa) wymaga przyjrzenia się specyficznej koncepcji wolności, którą Skinner nazywa „neoromańską wolnością cywilną”. Ta stanowi opozycję do doktryny Thomasa Hobbesa, opierającej się na przekonaniu, że właściwym piastunem suwerenności nie są ani zbiorowe ciało wspólnoty politycznej, ani jednostka w osobie króla. Podmiot polityczny, jak udowadnia Hobbes, nabiera charakteru suwerena przez to, że stanowi (jako państwo) osobę samą w sobie. Ta jest zapośredniczona przez reprezentantów piastujących aktualną władzę, co dokonuje się w drodze aktu przeniesienia jednostkowych uprawnień, które to uprawnienia przypisane są poszczególnym osobom w stanie przedpaństwowym, więc takim, w którym ze względu na brak "osoby neutralnej" niemożliwe jest przydanie jednostkowym uprawnieniom charakteru norm obarczonych sankcją. Sytuacja ta jest wynikiem niemożności narzucenia powszechnego sankcjonowania, a w dalszej kolejności ustalenia powszechnie honorowanych miar sprawiedliwości. Jednakże w rezultacie określenia sankcjonowanych norm wyznaczone zostają również podmiotowe prawa jednostek, które to wyznaczają granice dopuszczalnego ograniczenia wolności. Oznacza to, że dla Hobbesa właściwa wolność istnieje jedynie tam, gdzie prawo nie jest aktywne. Takie gwarancjonistyczne rozumienie prawa funduje sytuację, kiedy to możliwe staje się podejmowanie przez jednostki działań swobodnych i pozbawionych zewnętrznej interwencji wszędzie tam, skąd prawo przedmiotowe się wycofuje, a nawet w ogóle się nie pojawia.

Wydaje się, że taki sposób pojmowania wolności stał się najbardziej rozpowszechniony w liberalizmie, który w samych jednostkach lokuje skłonność do niepodejmowania działań wymierzonych w przestrzeń wolności innych ${ }^{3}$. W modelu Hobbesa obawa przed konsekwencjami naruszenia normy wcale nie redukuje wolności jednostki, ponieważ jest ona rozumiana jako wyraz poddania się nakazom instynktu bądź rozumu4 ${ }^{4}$ Oczywiście należy przy tym postawić pyta-

2 Republicanism, [w:] Stanford encyclopedia of philosophy, http://plato.stanford.edu/entries/republicanism/ (28. 12.2014).

3 J. S. Mill, On liberty, [w:] On liberty and other essays, ed. J. Gray, Oxford 1991, s. 17.

4 Q. Skinner, Liberty before liberalism, Cambridge 1998, s. 9-12. 
nie, czy wyznaczenie granic obszaru swobodnego korzystania z uprawnień własnych przez jednostkę nie jest jako takie ograniczeniem wolności. Wedle Hobbesa prawo i wolność nie mogą istnieć $w$ tej samej sprawie, zatem to w prawie przedmiotowym należy ulokować granice wolności poszczególnych jednostek. Jednocześnie należy mieć na uwadze, że wedle powyższego ujęcia prawem natury jest rozpoznawany przez rozum każdego człowieka nakaz unikania tego, co dla życia niszczące ${ }^{5}$.

Republikańska nieufność wobec elementów doktryny Hobbesa dotyczy w głównej mierze wątpliwości co do rzeczywistej neutralności proponowanej osoby sztucznej. Czy naprawdę „osoba neutralna” musi znajdować się poza wspólnotą polityczną, być zewnętrzna wobec jej członków? Czy odpodmiotowienie osoby sztucznej niesie za sobą jakieś ryzyko? Te wątpliwości nowożytni republikanie wiązali z wczesnonowożytnymi i antycznymi pismami, w których podnoszono związek indywidualnej wolności z wolnością wspólnoty politycznej, nawet w odwrotnej kolejności ${ }^{6}$. Tu republika rozumiana jako pożytki wynikające ze wspólnego bytowania była modelem wspólnoty, która sama decydując o swojej przyszłości, jednocześnie gwarantowała wolność swoich obywateli ${ }^{7}$. Co więcej, nowożytni angielscy republikanie utożsamiali wolność z zestawem uprawnień danym każdej jednostce, która również z mocy natury winna być wolną. Trwałość tego zestawu jest determinantą wolności w ogóle ${ }^{8}$. Świadomość tego stanu rzeczy pcha poszczególne osoby ku przekonaniu, że indywidualna wolność zależy od istnienia współtworzonej przezeń wspólnoty politycznej, opartej na zdolności rozeznawania treści wolności lub uprawnień poprzez poszczególnych jej członków. Rozumność każdej osoby rodzi świadomość wielości namiętności rządzących poszczególnymi jednostkami i właśnie dlatego kieruje ku wspólnocie, zdolnej owe namiętności okiełznać poprzez rozwój rozumu i w dalszej kolejności cnoty9 . W tym sensie nowożytny republikanizm można

5 T. Hobbes, Lewiatan, czyli materia, forma i władza państwa kościelnego i świeckiego, przeł. C. Znamierowski, Warszawa 1954, s. 111.

6 Cicero, De Officiis, trans. Adrew P. Peabody, Boston 1887, s. 111.

7 M. Viroli, Republicanism, New York 2002, s. 55.

8 A. Grześkowiak-Krwawicz, Quentin Skinner i teoria wolności republikańskiej, „Archiwum Filozofii i Myśli Społecznej" t. 45 (2000), s. 165-174.

9 W. R. E. Velema, That a republic is better than a monarchy: anti-monarchism in early modern Dutch political thought, [w:] Republicanism, vol. I, Republicanism and constitutionalism in early modern Europe: a shared European heritage, ed. M. van Gelderen, Q. Skinner, Cambridge 2002, s. $14-15$. 
postrzegać jako obronę rządów rozumu przed zewnętrznym nieuporządkowanym światem namiętności. W rezultacie utworzenie republiki jest przedłużeniem rozumowych właściwości człowieka czy też koniecznością rozumną przeciwstawiającą się naturze ${ }^{10}$.

Nawiązując do powyższych argumentów, należy stwierdzić, że z jednej strony cnota polityczna jest warunkiem utrzymania wolności, z drugiej zaś jakością przynależną jedynie wąskiej grupie obywateli. Jednakże nawet w warunkach „nierównej dystrybucji cnoty” wszyscy obywatele muszą odznaczać się jakimś jej poziomem, jeśli republika ma być gwarantem wolności powszechnej ${ }^{11}$. Ten sposób opisywania obywateli w kategoriach normatywnych, w szczególności zaś mówienie o ich cnotach, jest cechą charakterystyczną przywołanego wcześniej humanizmu obywatelskiego. Mowa przecież o swoistej jakości reprezentantów, która wyraża się w ich dyspozycji do działania przekraczającego poziom indywidualny na rzecz poziomu wspólnotowego, dyspozycji o charakterze normatywnym. Takie określenie reprezentantów gwarantuje, że ciało polityczne będzie rządzone przez jego własnych członków, a zatem uda się uniknąć narzucanej z zewnątrz negacji wolności. Wszelaki stosunek podległości jest formą przełamania jednostkowej woli i uczynienia poszczególnych osób zależnymi, zniewolonymi. Niepodobna więc zachować wolność indywidualną, gdy odebrane zostaje uprawnienie do współuczestniczenia i współdecydowania co do treści norm prawa. Należy przy tym zauważyć, że wbrew zarzutom krytyków republikanie nie identyfikowali poziomu wolności indywidualnej z tą wspólnotową, a jedynie podkreślali komplementarne znaczenie obu ${ }^{12}$.

Założenie, że wolność indywidualna jest możliwa jedynie w warunkach wolnej wspólnoty, wiedzie ku sednu republikańskiego ujęcia wolności. Skoro zakłada się, że zabezpieczenie jej przez władzę cywilną jest konieczne i pożądane, to również można przyjąć, iż władca jest uprawniony do korzystania z dyskrecjonalnej władzy w takim wymiarze, w jakim jest to niezbędne dla zachowania wolności wspólnoty politycznej i w konsekwencji tej indywidualnej. Jednakże sam fakt scedowania tak ogromnego zakresu władzy stanowi de facto poddanie się choćby tylko potencjalnej, arbitralnej woli piastuna, a co za tym idzie uzależnie-

10 J. Scott, Classical republicanism in seventeenth century England and Netherlands, [w:] Republicanism, dz. cyt., s. 70.

11 Wyger R. E. Velema, That a republic is better than a monarchy, dz. cyt., s. 21.

12 P. Pettit, Republicanism. A theory of freedom and government, Oxford 1997, s. 73-74. 
niem się od niego ${ }^{13}$. Opisana przez Pettita „wolność jako brak dominacji” to nic innego jak sytuacja, kiedy to jednostka może rozporządzać sama sobą bez ryzyka wpływu z zewnątrz. Jednocześnie ograniczenie owego wpływu możliwe jest jedynie w warunkach wspólnoty, co oznacza, że konieczne jest takie zorganizowanie ustroju politycznego, które znosiłoby podobne ryzyko poprzez odebranie jakiemukolwiek organowi władzy arbitralnej czy dowolnej innej możliwości uzależniania realizacji uprawnień jednostek od zewnętrznej woli ${ }^{14}$. Zadanie to spełnić można poprzez włączenie wszystkich jednostek do procesu stanowienia prawa, czy to bezpośrednio, czy przez wybranych reprezentantów. Zatem dla tradycji republikańskiej podstawowym uzasadnieniem prawa jest uczynienie zeń oręża w obronie wolności politycznej wspólnoty, a w dalszej konsekwencji wolności indywidualnej jej członków ${ }^{15}$.

W nowoczesnym wariancie republikańskim odrzuca się więc bliski liberałom pogląd zakładający pierwotność uprawnień (wywodzonych z jakiejś koncepcji stanu natury). Komplementarność dwóch poziomów zachowywania wolności pozawala uniknąć sytuacji, w której jeden z nich dążyłby do skonsumowania drugiego. Jednocześnie wydaje się, że poprzez szerokie włączenie jednostek do procesów tworzenia prawa i jego kontrolowania republikanie chcą nie tylko ustanowić formę gwarancyjną dla zachowania obu poziomów wolności, ale również pragną zapewnić trwanie samemu ciału politycznemu jako podstawowemu warunkowi dla realizowania tychże. Dostrzeżono, że określanie mocą prawa prerogatyw stosowania legalnego przymusu przez konkretne organy jest jakąś formą ograniczania wolności, ponieważ wbrew tezom Hobbesa jednak nakazuje się konkretne zachowanie. Zminimalizowanie stanu zależności wymaga tedy włączenia jednostek do ustalania treści każdej z takich prerogatyw. Przeciwnie do liberałów republikanie podnosili, że ograniczenie wolności ma źródło nie tylko w przymusie prawa lub arbitralnej ingerencji, ale również w każdej innej dominacji, we wszelkiej zależności od „zewnętrznej” woli. Podczas gdy ingerencja jest działaniem lub zaniechaniem działania, dominacja to sytuacja ciągłego warunkowania woli jednostki poprzez strach bycia rozporządzanym ${ }^{16}$.

\footnotetext{
13 Q. Skinner, Liberty before liberalism, dz. cyt., s. 17.

14 P. Pettit, Republicanism, dz. cyt., s. 27-31.

15 Tamże, s. 171-205.

16 M. Viroli, Republicanism, dz. cyt., s. 36-37.
} 
Wszystko to oznacza, że - jak twierdzi Skinner - republikańska koncepcja wolności opiera się na nieobecności tak ingerencji lub wpływu (interference), jak również dominacji (domination). Stanowisko to podziela oczywiście Pettit, zauważający, że kwestia ewentualnego występowania ingerencji jest zdecydowanie mniejszym naruszeniem wolności. Podkreśla on bowiem, że charakterystyczne dla tradycji republikańskiej jest ujęcie kwestii ograniczenia wolnego rozporządzania wolą jednostek za pomocą prawa, które to ustanawia republikę. Wolność od jakiegokolwiek wpływu jest tu raczej postrzegana jako wolność od dowolności, czyli od stanu pewnego chaosu. Istnienie praw ma dla funkcjonowania republiki znaczenie fundamentalne, ale należy w tym momencie podkreślić, że zarówno Skinner, jak i Pettit przez wolność nie rozumieją jedynie podlegania prawom, które się samemu ustanowiło, i tym samym nie sprowadzają wolności do pozytywnego rozporządzania wolą.

Uzasadnienie dla istnienia prawa poprzez negatywną zasadę wolności w stanowisku republikańskim okazuje się szczególnie ciekawe, gdy zestawione jest z dychotomią wolności zaproponowaną przez Isaiaha Berlina ${ }^{17}$. Wedle tego autora wolność negatywna sprowadza się do całkowitej swobody rozporządzania własną wolą bez wtrącania się do tego innych. Taki zakres indywidualnego nieskrępowania musi być ograniczony mocą prawa, przy jednoczesnym zachowaniu pewnego nienaruszalnego minimum, które stanowi absolutną i niezbywalną przestrzeń wolności osobistej ${ }^{18}$. Zatem wolność i zmuszające prawo są niepołączalne i konieczne jest przeprowadzenie między nimi wyraźniej linii demarkacyjnej ${ }^{19}$. Winna ona mieć oparcie w przyjętym „a priori minimalnym obszarze ludzkiej wolności", do którego honorowania zobowiązany jest każdy piastun władzy, ponieważ jego naruszenie jest atakiem na samą w sobie naturę ludzką ${ }^{20}$. Innymi słowy, w treści zasady wolności negatywnej znajduje się imperatyw nakazujący orzeczenie o składnikach owego „minimalnego obszaru ludzkiej wolności". Problem w tym, że jednostki nie ustalają sobie jego treści, ale niejako rozpoznają ją. Co więcej, trzeba mieć przy tym na uwadze, że apel Berlina jest adresowany przede wszystkim do piastunów władzy, wobec tego rów-

17 I. Berlin, Dwie koncepcje wolności i inne eseje, wybór J. Jedlicki, przeł. D. Grinberg, Warszawa 1991, s. 113-115.

18 H. G. Frankfurt, Freedom of the will and the concept of a person, [w:] Free will, ed. G. Watson, Oxford 1982.

19 Pogląd ten wydaje się podobny do przywołanych wcześniej koncepcji Hobbesa.

20 I. Berlin, Dwie koncepcje wolności..., dz. cyt., s. 114-121. 
nież w gestii tychże leży realna możliwość orzekania na temat tego, co składa się na niezbywalną wolność każdej jednostki.

Dla republikanów problematyczne jest tu oczywiście nazwanie czy też wyznaczenie osoby tak sprawnej epistemicznie, by rzeczywiście była zdolna do orzeczenia obowiązującego wszystkich i również satysfakcjonującego ich samych minimalnego zakresu wolności. Jest to ryzyko o tyle realne, że możliwe jest takie określenie tego minimum, które de facto uniemożliwi korzystanie z jakichkolwiek uprawnień ${ }^{21}$. Za trafny należy więc uznać zarzut Skinnera, który obracając liberalną retorykę, widzi w propozycjach Berlina jedynie drobną gwarancję zachowania wolności, a nie jej podstawę. Wedle Skinnera to raczej neoromańscy republikanie odnajdują właściwą podstawę wolności ulokowaną w uprawnieniach jednostkowych utrzymywanych w wolnej wspólnocie politycznej opartej na samostanowieniu. Wolność tu rozumiana jako „brak dominacji" (freedom as non-domination) opiera się na przekonaniu, że utrzymanie wolności indywiduum jest zależne od wolności wspólnoty, która dostrzegając pożytki płynące z kooperacji, jednocześnie gwarantuje wolność poszczególnych części składowych. Oznacza to, że „zdolność epistemiczna” leży właśnie po ich stronie, przez co otrzymują oni potężne narzędzie zachowania swojego statusu podmiotowego z całym zakresem przynależnych mu uprawnień. „Wolność jako brak dominacji” to również sytuacja, w której podmiot cieszy się z niewystępowania zależności teraz lub w każdym innym potencjalnym momencie czy świecie. Innymi słowy, w przeciwieństwie do ideału „wolności jako braku wpływu” (freedom as non-interference) podmiot „wolny od dominacji” nie tylko cieszy się wolnością wyboru, ale przede wszystkim faktem, iż ów wybór nie jest zależny od arbitralnych warunków zewnętrznych ${ }^{22}$.

Tradycja republikańska zdaje się kłaść szczególny nacisk na zagrożenia czyhające na państwo, które poddaje się zależności². Wobec tego jednym z kluczowych elementów ich rozważań stała się cnota obywatelska, rozumiana jako zespół cech pozwalających jednostce służyć dobru wspólnemu. Jej materialnym przejawem był „nakaz” służby publicznej. Również na tym etapie widać mocne

21 B. Szlachta, Wolność republikańska. Na marginesie debaty o tradycji republikańskiej $w$ „atlantyckiej” myśli politycznej, „Państwo i Społeczeństwo. Półrocznik Krakowskiej Szkoły Wyższej im. Andrzeja Frycza Modrzewskiego" 1 (2001), s. 220.

22 P. Pettit, Republicanism, dz. cyt., s. 25.

23 Tenże, Republican freedom and contestatory democratization, [w:] Democracy's value, ed. I. Shapiro, Cambridge 1999, s. 165. 
inspiracje myślą klasyczną, która często akcentowała konieczność obywatelskiej aktywności dla trwania ładu politycznego ${ }^{24}$. Mowa tu o podejmowaniu wolnych od partykularyzmów działań powodowanych troską o wspólnotę ${ }^{25}$. Nakaz służby publicznej nie jest sprzeczny z wolnością jednostki, ponieważ służba stanowi warunek i gwarancje wolności jednostki i wspólnoty zarazem ${ }^{26}$. Skinner podkreśla, że prawdziwie wolnym może być jedynie ten, kto odrzucił od siebie wszelkie zagrożenie dominacją przez to, że działając na rzecz dobra wspólnego, zneutralizował siłę poszczególnych partykularyzmów ${ }^{27}$. Pierwotnych źródeł zniewolenia należy się tedy dopatrywać nie w naruszeniu jakiś przyrodzonych uprawnień drugiego człowieka, ale raczej w haniebnym zaniechaniu dobra wspólnego.

Rodzi się tu jednak problem wyjątkowej wagi, albowiem zgadzając się na proponowany model wspólnoty, republikanie stają przed koniecznością wykazania pewnych podstaw, na których należałoby przytaczaną cnotę obywatelską ufundować. Jeśli bowiem relacja między wolnością jednostkową a wspólnotową ma tak duże znaczenie dla zabezpieczenia „wolności jako braku dominacji”, to wówczas należy wykazać, w jaki sposób poszczególne jednostki funkcjonujące już w obrębie wspólnoty włączają się do procesów prawotwórczych. Co wpływa na jednostki tak, że kieruje je ku współdziałaniu w ramach wspólnoty, o którym to współdziałaniu są one skłonne mówić w kategoriach obowiązku moralnego?

Skinner podejmuje próby rozładowania tego napięcia, zwracając uwagę na fakt, że tradycji republikańskiej bliższe niż indywidualistyczne pojmowanie wolności jest to wywodzące się od Arystotelesa. Owo zaś akcentuje wewnętrzną skłonność człowieka do działania na rzecz dobra wspólnego, nie wbrew własnym uprawnieniom, ale właśnie w zgodzie z nimi, a w dalszej konsekwencji nawet i w ich interesie ${ }^{28}$. Mamy tu więc do czynienia z przyrodzoną wszystkim ludziom skłonnością, która pobudzając rozum, kieruje jednostki ku wspólnocie. W sensie filozofii Arystotelesa taki impuls ma z jednej strony charakter racjonalny, z drugiej zaś normatywny, albowiem jedynie w warunkach wspólnoty możli-

24 Cyceron, O państwie. O prawach, przeł. I. Żółtowska. Kęty 1999, s. 14.

25 Tenże, Sen Scypiona, przeł. I. Wieniewski, Łódź 1994, s. 16.

26 Cnoty polityczne - dawniej i obecnie. Moralne źródła polityki, red. R. Piekarski, Gdańsk 1997, s. $43-58$.

27 Q.Skinner, The republican ideal of political liberty, [w:] Machiavelliand republicanism, ed. G. Bock, Q. Skinner, M. Viroli, Cambridge 1990, s. 294-295.

28 H. Arendt, Kondycja ludzka, przeł. A. Łagodzka, Warszawa 2010, s. 42, 94-95. 
we jest realizowanie sensu natury ludzkiej, jakim jest działanie polityczne i tym samym osiągnięcie optimum człowieczeństwa ${ }^{29}$. Normatywność impulsu prowadzi do przekonania, że o działaniach z niego wypływających możemy mówić jako o działaniach moralnych i w tym sensie powiązać je z cnotą. Drugą konsekwencją takiego klasycznego sposobu rozumowania jest zgoda na istnienie ontologicznej podstawy, z której można wywodzić treść racjonalności i w dalszej kolejności poszczególnych zachowań (o których możemy powiedzieć że są dobre bądź złe).

Bezpośrednie odwołanie się do tradycji antycznej ma oczywiście swoje miejsce w tradycji obywatelskiego humanizmu i było ważnym źródłem inspiracji dla tradycji renesansowej. Powoduje to jednak problem swoistego dualizmu, który polega na tym, że dla zabezpieczenia wolności jednostek i wspólnoty powołujemy się na obowiązek moralny względem tejże wspólnoty, który to obowiązek ulokowany jest na zewnątrz jednostek. Jeśli utrzymać przy tym charakterystyczny dla nowoczesnego republikanizmu (civic republicanism) argument o braku jednostki na tyle sprawnej epistemicznie, by mogła być zdolna rozpoznawać powszechnie uznawane miary sprawiedliwości, wówczas należy dojść do wniosku, że nowoczesny republikanizm, obawiając się swoistej dyktatury cnót, nie może przyjąć domniemania istnienia obowiązków obywatelskich. Jakkolwiek istnieje domniemanie pewnej racjonalności obywateli i zanurzenia ich we wspólnej kulturze, to wydaje się ono niewystarczające dla zbudowania koherentnego modelu $^{30}$. Zwracał na to uwagę sam Machiavelli, twierdząc, że uprawnienia mają charakter raczej historyczny niż naturalny i choćby z tego powodu muszą one zostać zabezpieczone prawem, by móc postrzegać je jako coś więcej niż tylko moralne żądania ${ }^{31}$. Co więcej, dokonywanie podziału społeczeństwa na te jednostki, które wykazują się większą i mniejszą cnotą, prowadzi do swoistej segmentacji wspólnoty, co samo w sobie wydaje się niezgodne z duchem republikańskich refleksji ${ }^{32}$.

29 Tym, co szczególnie ludzkie, ma być skłonność do działania politycznego wypływająca z przypisanej każdemu człowiekowi natury. Patrz. zoon politikon.

30 B. Hidness, Very idea of modern republic, [w:] Republicanism, citizenship, community. ed. G. Hage, L. Johnson, Nepean 1996, s. 2-4.

31 M. Viroli, Republicanism, dz. cyt., s. 7.

32 J. F. Spitz, From civism to civility: D'Holbach's critique of republican virtue, [w:] Republicanism, citizenship, community, dz. cyt., s. 108-111. 
Cnota jest więc tu postrzegana jako przyrodzona tendencja, która jest niejako odkrywana w toku rozwoju indywidualnego każdej jednostki. Tym samym odkrycie cnoty jest swoistym obowiązkiem, jaki jednostka winna jest zrealizować względem wspólnoty politycznej, jeśli ta ma przetrwać i jednocześnie gwarantować „wolność jako brak dominacji”. Ów obowiązek moralny ma charakter zewnętrzny względem jednostki, co oznacza że ulokowany w bliżej nieokreślonym „miejscu”. W tradycji antycznej była nim swoiście pojmowana natura ludzka. Nowoczesny republikanizm jednak nie jest w stanie zgodzić się na poszukiwanie zewnętrznych ontologicznych źródeł obowiązków moralnych czy też tendencji gatunkowych, albowiem jest to sprzeczne ze wspomnianym wcześniej założeniem epistemologicznym. Przełamanie tego założenia na rzecz poszukiwania źródeł cnoty czy obowiązków obywatelskich jest zatem wystąpieniem dominacji, albowiem jak zwraca uwagę Pettit, mamy tu do czynienia z sytuacją, kiedy to pewną interpretację rzeczywistości można postrzegać jako przejaw czyjejś arbitralnej woli ${ }^{33}$. Jeśli pojawi się w społeczeństwie przekonanie, że postępować należy w konkretny sposób, i jeśli to przekonanie nie wypływa bezpośrednio z jednostek, wówczas mamy do czynienia z dominacją ${ }^{34}$.

Problem dotyczy fundamentu wspólnoty republikańskiej, momentu wspólnotowego, który to łączy poszczególne indywidualistycznie nastawione jednostki w przekraczającą ich indywidualizm wspólnotę. W tejże zakotwiczone są interesy poszczególnych jednostek, które to ulegają swoistemu pogodzeniu (ale nie zagregowaniu) gwarantującym tym samym pokojowe współegzystowanie. Współczesny republikanizm (inaczej niż humanizm obywatelski) odrzuca wszelkie próby poszukiwania takich źródeł w bytach zewnętrznych, których ontologiczną naturę dałoby się w jakiś sposób orzec. Brak tu zatem miejsca na naturę gatunkową, hipotetyczny stan natury, umowę społeczną czy też powszechną rozumność. Podstawowy dla krytyki fenomenu „wolności jako braku ingerencji” epistemologiczny argument Pettita i Skinnera wydaje się nie do pogodzenia z postulowaną przez nich normatywnie ukonstytuowaną kulturą obywatelską. Przełamanie tego impasu poprzez wprowadzenie jakiegoś modelu kompetencji komunikacyjnych, rozumu komunikacyjnego czy wreszcie szacunku dla zastanych norm jawi się to jako zabieg niewystarczający, albowiem odnoszący się

33 P. Pettit, Republicanism, dz. cyt., s. 52-53.

34 Tamże, s. 58-59. 
tylko do konkretnego momentu historycznego i kulturowego ${ }^{35}$. Również mało satysfakcjonujący wydaje się argument Pettita, który twierdzi, że współczesny republikanizm postrzega siebie bardziej jako teorię praktyczną, odcinającą się od tendencji metafizycznych na rzecz urzeczywistnienia ideału „wolności jako braku dominacji” ${ }^{36}$. Wynikające z tego „praktycznego" stanowiska twierdzenie o naczelnej roli prawa w organizacji społeczeństwa i mającej z tego wynikać kulturze obywatelskiej opiera się na przekonaniu, iż to właśnie z samego faktu istnienia prawa wywodzi się kultura obywatelska. Zatem porządek prawny poprzedza impuls wspólnotowy, który to z kolei impuls jest przecież konieczny dla zaistnienia porządku prawnego w ogóle ${ }^{37}$.

Wydaje się, że największą kontrowersję w nowoczesnym republikanizmie powoduje problem połączenia fenomenu wartości politycznych z instytucjami je egzekwującymi i w konsekwencji tego wytworzenia się źródeł identyfikacji obywatelskiej w sensie fundamentu, z którego można czerpać uzasadnienie dla republikańskiej koncepcji wolności ${ }^{38}$. Jeśli zatem nowoczesny republikanizm pretenduje do miana teorii szerokiego zasięgu i tym samym korekty liberalizmu, to konieczne jest zaproponowanie takiego właśnie twardszego fundamentu dla momentu wspólnotowego.

\section{Bibliografia}

Arendt H., Kondycja ludzka, przeł. A. Łagodzka, Warszawa 2010.

Berlin I., Dwie koncepcje wolności i inne eseje, wybór J. Jedlicki, przeł. D. Grinberg, Warszawa 1991.

Cnoty polityczne - dawniej i obecnie. Moralne źródła polityki, red. R. Piekarski, Gdańsk 1997.

Cyceron, O państwie. O prawach, przeł. I. Żółtowska, Kęty 1999.

Cyceron, De Officiis, przeł. A. P. Peabody, Boston 1887.

Cyceron, Sen Scypiona, przeł. I. Wieniewski, Łódź 1994.

Democracy's value, ed. I. Shapiro, Cambridge 1999.

35 Tamże, s. 189, 248-251.

36 Tamże, s. 240.

37 L. Andronache, Contemporary republican theories: in the search of solidarity, [w:] Republicanism in theory and practice, ed. I. Honohan, J. Jennings, Routledge 2006, s. 111-116.

38 P. Mouritsen, Four models of republican liberty and self-government, [w:] Republicanism in theory and practice, dz. cyt., s. 19-21. 
Free will, ed. G. Watson, Oxford 1982.

Grześkowiak-Krwawicz A., Quentin Skinner i teoria wolności republikańskiej, „Archiwum Filozofii i Myśli Społecznej" t. 45 (2000), s. 165-174.

Hobbes T., Lewiatan, czyli materia, forma i władza państwa kościelnego i świeckiego,

przeł. C. Znamierowski, Warszawa 1954.

Machiavelli and republicanism, ed. G. Bock, Q. Skinner, M. Viroli, Cambridge 1990.

Mill Stuart J., On liberty and other essays, ed. J. Gray, Oxford 1991.

Pettit P., Republicanism. A theory of freedom and government, Oxford 1997.

Powrót wielkiej teorii w naukach humanistycznych, red. B. Szlachta, przeł. P. Łozowski, Lublin 1998.

Republicanism, citizenship, community, ed. G. Hage, L. Johnson, Nepean 1996.

Republicanism in theory and practice, ed. I. Honohan, J. Jennings, Routledge 2006.

Republicanism, vol. I, Republicanism and constitutionalism in early modern Europe:

a shared European heritage, ed. M. van Gelderen, Q. Skinner, Cambridge 2002.

Skinner Q., Liberty before liberalism, Cambridge 1998.

Szlachta B., Wolność republikańska. Na marginesie debaty o tradycji republikańskiej w „atlantyckiej” myśli politycznej, „Państwo i Społeczeństwo. Półrocznik Krakowskiej Szkoły Wyższej im. Andrzeja Frycza Modrzewskiego” 1 (2001).

Viroli M., Republicanism, New York 2002. 